\title{
Quantification and Determination of Starch in Diets Using Different Methodologies: Infrared Spectroscopy with Fourier Transformer, Laser Diffraction and Enzymatic Analysis
}

\author{
Andressa Nathalie Nunes, Eloisa de Oliveira Simões Saliba, Dalton Oliveira Fontes, \\ Ana Tereza Peret Dell'Isola, Tatiana Carolina Gomes Dutra de Souza, Poliana Campos, \\ Esmaile Perceu Rocha Nunes, Jaqueline Simões Saliba, Ludhiana Rosa Ferreira \\ Universidade Federal de Minas Gerais (UFMG), Belo Horizonte, Brazil \\ Email: natydressa2009@hotmail.com, saliba@ufmg.br, daltonfontes@ufmg.br, atperet@ufv.br, tatianacdutra@hotmail.com, \\ polianacampos@ymail.com,zoo.esmaile@yahoo.com.br,jaquelinesaliba@yahoo.com.br, ludhiana_16@gmail.com
}

How to cite this paper: Nunes, A.N., Saliba, E.O.S., Fontes, D.O., Dell'Isola, A.T.P., de Souza, T.C.G.D., Campos, P., Nunes, E.P.R., Saliba, J.S. and Ferreira, L.R. (2017) Quantification and Determination of Starch in Diets Using Different Methodologies: Infrared Spectroscopy with Fourier Transformer, Laser Diffraction and Enzymatic Analysis. American Journal of Analytical Chemistry, 8, 151-157. https://doi.org/10.4236/ajac.2017.82012

Received: December 6, 2016

Accepted: February 20, 2017

Published: February 23, 2017

Copyright (c) 2017 by authors and Scientific Research Publishing Inc. This work is licensed under the Creative Commons Attribution International License (CC BY 4.0).

http://creativecommons.org/licenses/by/4.0/ (c) (i) Open Access

\begin{abstract}
A digestibility experiment was conducted in the Animal Nutrition Laboratory of the Veterinary School of the Federal University of Minas Gerais (UFMG), Protocol ethics committee for work with animal experimentation CETEA/ UFMG 212/2010, in order to validate the instrumental techniques Laser Diffraction (Partica) and Infrared Spectroscopy with Fourier Transformer (FTIR) method, as replacement methods of the reference (Enzymatic Analysis) Technique, of starch quantification in diets of growing pigs. The experiment lasted 12 days ( 7 days of adaptation to the cage and diet and 5 days of total collection). Fifteen barrows with average weight of $\pm 25 \mathrm{~kg}$ and 65 days old were used for this study. A completely randomized experimental design was adopted, with split plots and subplots. The plots were the diets (1-Reference, 2 -Reference + inclusion of 30\% micronized soybean and 3-Reference $+30 \%$ substitution of plasma) and the subplots were the techniques (Partica, FTIR and Enzymatic Technique, with five repetitions (animals) per diet). The results obtained with the Partica and FTIR techniques were compared to the reference method. There was no statistical difference $(\mathrm{p}>5 \%)$ between these techniques evaluated in comparison to the reference method to quantify starch. However, it was observed that the FTIR technique was different from the reference method for $(\mathrm{p}>5 \%)$ overestimating the means of evaluated samples.
\end{abstract}

\section{Keywords}

Instrumental Techniques, Enzymatic Technique, Quantification of Starch 


\section{Introduction}

The feed starch is quantified by the amount of glucose released after its complete enzymatic hydrolysis, by using a combined of amylolytic enzymes [1]. The $\alpha$ amylase promotes fragmentation of the starch molecule by hydrolysis to produce reducing sugars of low molecular weight (maltose, maltotriose and maltotetrose). However, this enzyme does not hydrolyze glycosidic bonds present in amylopectin and therefore the amiloglicosidasis must be used for complete hydrolysis of starch to glucose. However, techniques based on this principle are not efficient for the determination of resistant starch. Therefore, from the $80 \mathrm{~s}$, efforts were concentrated on developing techniques that addressed the determination jointly or separately, of these two fractions, for better results and a higher reliability, those named instrumental techniques, faster, easier and more accurate in their results.

The study of the chemical composition of feeds can be done by conventional chemical techniques or by instrumental techniques (use of equipment). For the use of instrumental techniques such as Infrared Spectroscopy with Fourier Transformer (FTIR) and Laser Diffraction (Partica), the prior standardization is necessary, made from comparisons with standard techniques Enzymatic Analysis.

Principle of Particle Technique is based on the measurement of the particle size of the sample, where the instrument detects the correlation between the intensity and the angle of the diffracted light of the particles and calculates its size by Mie diffraction.

The smaller the wavelength of a beam of light, the particles are smaller, and has a higher diffraction angle.

The infrared region in the electromagnetic spectrum comprises radiation ranging from 14000 to $10 \mathrm{~cm}^{-1}$; or wavelength from 0.7 to $1000 \mu \mathrm{m}$. The objective of infrared absorption spectroscopy is to determine the functional groups of a given material. Each group absorbs the characteristic frequency of radiation in this region of the electromagnetic spectrum. Thus, a graph of intensity of radiation versus frequency, the infrared spectrogram, allows to characterize the functional groups of a pattern or an unknown material. This is one of the analytical techniques that have more applications, and can be used for qualitative and quantitative [2].

It evaluated the starch concentration in the root of cassava genotypes through enzymatic techniques, Fourier Transform Infrared Spectroscopy (FTIR) and a particular analysis by laser diffraction (Partica). The conventional (enzymatic) method is proved to be the most laborious and subject to variations in results. The instrumental methods were promising for their use in the determination of starch, by the uniformity of their results and speed of execution [3].

\section{Materials and Methods}

The experiment was conducted in the Laboratory of Animal Metabolism, Department of Animal Science, School of Veterinary Medicine, Federal University of Minas Gerais. 
We used in this experiment 15 swine barrows of commercial line DB Dambred aged 65 days old and with initial weight of $\pm 25 \mathrm{~kg}$. The animals were housed individually in metabolic cages fitted with feeder, drinker, individual collector of feces and urine for a period of 7 days for adaptation and 5 days of collection. The trial lasted 12 days.

The experimental diets were manufactured from a basal diet (T1) described in Table 1.

The diets corresponding to the other dietary treatments ( $\mathrm{T} 3$ and $\mathrm{T} 2$ ) are characterized by substitution in the second diet of $30 \%$ of the basal diet with micronized soybean and in the third diet, replacement of $30 \%$ of the basal diet with blood plasma. Diets were formulated to meet the requirements of animals, according to the dietary recommendations of [4]. Diets were fed moistened twice a day, one at 6:00 in the morning and the other at 18:00 in the afternoon. Established feed intake was according to the metabolic weight of each animal. Water was provided ad libitum. The digestibility markers were administered orally. LIPE ${ }^{\circledR}$ was supplied in capsule form, one capsule of $0.25 \mathrm{~g}$ per animal per day. Chromium Oxide and $\mathrm{Ti}$ tanium Dioxide were mixed to the ration when they were prepared, with $0.8 \mathrm{~kg}$ of markers $\left(\mathrm{Cr}_{2} \mathrm{O}_{3}\right.$ and $\left.\mathrm{TiO}_{2}\right)$ to every $100 \mathrm{~kg}$ of diet. Each pig received an average of $0.8 \%$ of each marker $\left(\mathrm{TiO}_{2}\right.$ and $\left.\mathrm{Cr}_{2} \mathrm{O}_{3}\right)$ daily with the feed during the whole experimental period. Table 2 describes the chemical composition of the diets for the ratio of $100 \% \mathrm{DM}^{*}$ of the experimental diets.

The determination of the apparent digestibility of the diets was carried out through the traditional method of feces Total Collection and using the external marker of digestibility LIPE ${ }^{\bullet}$ according to [5], Chromium according to [6], and Titanium according to [7], and Short et al. 1996; through calculations and laboratory analyses. The experimental period was 12 days, 7 days for adjustment

Table 1. Percentage composition of the reference diets.

\begin{tabular}{cc}
\hline Ingredients & $\mathrm{T} 1$ \\
\hline Corn (grain) & 69.3 \\
Soybean meal & 24.9 \\
Meat meal & 4.4 \\
Growth premix & 0.4 \\
Calcarium & 0.5 \\
Salt & 0.5 \\
Chromic oxide inclusion & 0.8 \\
Titanium dioxide Inclusion & 0.8 \\
\hline
\end{tabular}

*Vitamined mineral Premix per kg of product: vit. A, 2,000,000 UI; vit. $\mathrm{D}_{3}, 300,000$ UI; vit. E, $5000 \mathrm{mg}$; vit $\mathrm{K}_{3}, 625 \mathrm{mg}$; vit. $\mathrm{B}_{1}, 250 \mathrm{mg}$; vit. $\mathrm{B}_{2}, 1000 \mathrm{mg}$; vit. $\mathrm{B}_{6}, 500 \mathrm{mg}$; vit. $\mathrm{B}_{12}, 5000 \mathrm{mcg}$; Nicotinic acid, $625 \mathrm{mg}$; Nelenium, 125 mg; Biotin, 12.5 mg; Antioxidant, 30,000 mg; e vehicle q.s.p., 1000 g, Pantotenic acid 2500 mg; Folic acid $150 \mathrm{mg}$; Choline 60,000 mg; vit. C 12,500 mg; Metionin 25,000 mg; Threonine 10,000 mg; Tripsin. $5000 \mathrm{mg} ; 125 \mathrm{mg}$ Selenium, Iodine $200 \mathrm{mg}, 125 \mathrm{mg}$ Cobalt, Iron 17,500 mg; 100,000 mg Lysine; 5000 mg Copper, Manganese 10,000 mg; 20,000 mg Zinc; Tylosin 11,000 mg; 500 mg BHT. 
Table 2. Mean and standard error of the bromatological media of the experimental rations.

\begin{tabular}{cccc}
\hline \multirow{2}{*}{ Nutritional composition } & \multicolumn{3}{c}{ Dietas $^{*}$} \\
\cline { 2 - 4 } & Reference & $\begin{array}{c}\text { 30\% micronized } \\
\text { soybean }\end{array}$ & 30\% blood plasma \\
\hline MS & $87.29 \pm 1.74$ & $89.52 \pm 1.34$ & $87.17 \pm 1.57$ \\
EE & $4.17 \pm 0.04$ & $9.43 \pm 0.18$ & $2.36 \pm 0.01$ \\
FDN & $13.6 \pm 0.16$ & $15.4 \pm 0.23$ & $18.7 \pm 0.31$ \\
MM & $0.10 \pm 0.001$ & $0.08 \pm 0.0004$ & $0.09 \pm 0.0005$ \\
CA & $1.07 \pm 0.016$ & $0.99 \pm 0.014$ & $0.67 \pm 0.008$ \\
P & $0.63 \pm 0.005$ & $0.64 \pm 0.004$ & $0.81 \pm 0.007$ \\
PB & $21.14 \pm 0.317$ & $27.34 \pm 0.683$ & $35.85 \pm 1.254$ \\
EBcal/g & $4657.125 \pm 69.856$ & $5008.388 \pm 125.209$ & $4977.213 \pm 99.544$ \\
\hline
\end{tabular}

${ }^{*}$ DM: Dry matter.

to the cages, diets and for determination of intake, and 5 days for collection. The amount of ration given to animals, leftovers and feces were weighed daily over a period of 24 hours. The collected material was weighed, placed in plastic bags and stored frozen until the end of the collection period for further analysis.

The laboratory analyses of the diets and feces of the experiment were conducted in the Laboratory of Animal Nutrition, School of Veterinary Medicine of UFMG.

Feces were placed in a forced ventilation greenhouse at $55^{\circ} \mathrm{C}$ for 72 hours for pre-drying. After pre-drying, the material was exposed for two hours at room temperature, then weighed, homogenized and ground to $1 \mathrm{~mm}$ in a Willey mill type with sieves, and packaged in plastic pots properly identified. The chemical analyses of the experiment were dry matter (DM) in greenhouse at $105^{\circ} \mathrm{C}$, according to [8]. Ethereal Extract (EE) was by Goldfisch equipment. Determination of calcium (Ca) was by the Atomic Absorption Spectrophotometer, Phosphorus (P) by colorimetry, mineral matter $(\mathrm{MM})$ by burning in oven at $600^{\circ} \mathrm{C}$. Crude protein (PB) was by the Kjeldahl method according to [9], neutral detergent fiber (NDF) method [9]. Gross energy in a calorimetric pump (EB) was according to techniques described by [10]. Starch analysis was performed using Partica LA 950 Horiba ${ }^{\oplus}$ equipment (technique 1), FTIR infrared spectrophotometer through software provided by Varian Resolutions $s^{\circledast} 800$ (technique 2), and the enzymatic analysis of starch was performed using the glucose kit (Technique 3).

Formulas Used for Calculations:

${ }^{\star}$ Pre dried matter: $\mathrm{PDM}=($ weight of wet feces $)-($ pre-dried fecal weight $) \times$ 100.

${ }^{\star}$ Dry matter: Moisture $=100-\mathrm{MS105} \mathrm{C}$.

${ }^{*}$ Total dry matter: $\mathrm{TDM}=\left(\mathrm{DM} 105^{\circ} \mathrm{C} / 100\right) \times(\mathrm{MPS} / 100)$.

Data for formulas.

${ }^{\star}$ Fecal Output (FO).

${ }^{\star}$ Dry matter intake $(\mathrm{DMI})=\mathrm{DM}$ Ingested.

${ }^{\star}$ Dry matter digestibility (DMD). 


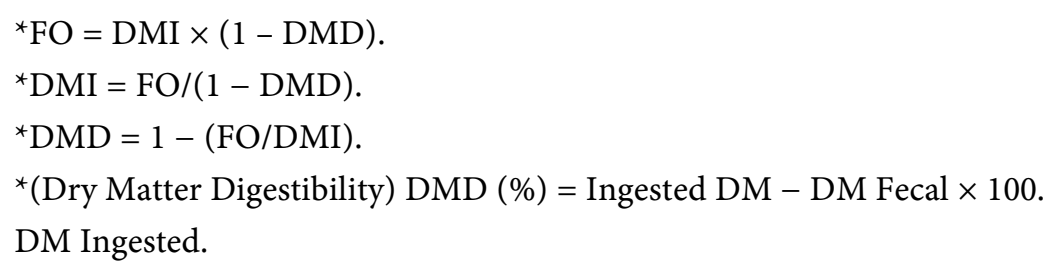

The calculations of concentration of starch were made directly by the software in the apparatus, both the device Partica and FTIR.

The quantification of the starch was performed by instrumental techniques Partica Horiba LA $950^{\circ}$, and by FTIR software from Varian Resolutions ${ }^{\circledR} 800$ and compared to the reference technique (enzyme analysis) in a randomized non-parametric statistical method of Dunn $(\mathrm{p}<0.05)$ for comparing the Friedman test groups $(\mathrm{p}>0.05)$. Medians in the same column used the Kruskal-Wallis test $(\mathrm{p}>0.05)$.

Statistical analysis of the determination of starch was by instrumental techniques Partica (technique 1) Horiba LA 950, and by FTIR (technique 2) software from Varian Resolutions ${ }^{\oplus} 800$ compared with the reference techniqueenzyme analysis (technique 3). A completely randomized design with split plots was made. The plots were the diets and subplots were enzymatic techniques, FTIR and Partica with 5 repetitions (animal) per treatment.

The data were subjected to analysis of variance using the statistical package SAEG version 9.0 [11], and means were compared by the Tukey test at 5\% probability of error.

\section{Results and Discussion}

In Table 3, it shows the starch percentage in each technique and in each diet.

The starch concentration technique determined with the Partica yielded results closer to the ones obtained through the calculations according to the usage of literature data.

The starch quantifying technique with the Partica equipment was similar to the enzymatic technique and in accordance with the calculated starch in the diet, however the technique by the FTIR apparatus was different from technical reference data, thereby overestimating the concentration of starch in the diet.

There was no statistical difference between the techniques evaluated. However it is visible that the value of the starch concentration was overestimated by the FTIR technique when compared to the Partica and reference method.

Within each diet there was statistical difference for the techniques evaluated. In Diet 1, only technique 2 was similar to the technique 1, and technique 3 was different from the reference method, but was statistically equal to technique 2 .

On Diet 2 both techniques tested 2 and 3, were statistically equal to the reference method, but different between themselves.

In Diet 3, technique 3 was statistically different from the reference method, however equal to technique 2 .

In Table 4, it shows the starch digestibility by each technique and in each diet. The results show that the Partica technique can be used to evaluate the digestibility 
Table 3. Starch percentage in each technique. Comparison of the 3 techniques: Partica, FTIR and enzymatic analysis.

\begin{tabular}{ccccc}
\hline \multicolumn{5}{c}{ Techniques } \\
\hline \% starch in diets & Enzymatic & Partica & FTIR & $\begin{array}{c}\text { Calculated } \\
\text { diet starch }\end{array}$ \\
\hline Reference diet (1) & $37.5 \mathrm{~b}$ & $45.0 \mathrm{ab}$ & $134.6 \mathrm{a}$ & 44.94 \\
Micronized soybean & $(31.2-45.4)$ & $(40.5-50.1)$ & $(115.1-218.5)$ & \\
(30\%) diet (2) & $(39.4 \mathrm{ab}-52.2)$ & $(36.0 \mathrm{~b}$ & $118.7 \mathrm{a}$ & 34.37 \\
Blood plasma (30\%) & $36.5 \mathrm{~b}$ & $41.4 \mathrm{ab}$ & $(100.4-238.8)$ & \\
diet (3) & $(33.7-41.8)$ & $(40.5-56.0)$ & $(102.8-238.8)$ & 31.46 \\
\hline
\end{tabular}

Averages followed by distinct lowercase letters in the same line represent statistical difference by the Dunn method $(\mathrm{p}<0.05)$ for group comparisons in the Friedman test $(\mathrm{p}>0.05)$.

Table 4. Mean and standard error of starch digestibility of diets.

\begin{tabular}{cccc}
\hline & \multicolumn{3}{c}{ Techniques } \\
\hline Diets & Enzymatic (\%) & Partica (\%) & FTIR (\%) \\
1 & $89.5 \pm 0.96 \mathrm{aA}$ & $89.1 \pm 0.90 \mathrm{Aa}$ & $80.3 \pm 2.80 \mathrm{aB}$ \\
2 & $84.0 \pm 0.81 \mathrm{aA}$ & $80.4 \pm 1.45 \mathrm{bA}$ & $85.5 \pm 3.43 \mathrm{aA}$ \\
3 & $85.6 \pm 1.30 \mathrm{aA}$ & $83.3 \pm 1.77 \mathrm{abA}$ & $85.8 \pm 1.99 \mathrm{aA}$ \\
\hline
\end{tabular}

$\mathrm{CV}=4.39 \%$. Different lower case letters in the column sandupper case in the rows differ statistically by the Tukey test at $5 \%$ probability.

of the starch in the diet 1 and diet 3, with respect to enzymatic technique, but it is not recommended to assess digestibility of starch in Diet 2. However, the FTIR technique can be used to evaluate the digestibility of the starch in the diets 2 and 3. It is not recommended to evaluate the digestibility of starch in the diet 1 compared to the reference technique, which is recommended to analyze all diets in this context.

\section{Conclusions}

The technique of the Partica was similar to the reference (method enzimatic) for quantification of starch in the diet, and also was similar to that calculated concentration of starch.

The starch digestibility by FTIR technique was similar to the enzymatic technique, for diet 2 and 3, demonstrating that the FTIR technique was better than the Partica technique, and may be suggested to replace the enzymatic technique to quantify starch.

\section{References}

[1] Asp, N.G. (1996) Dietary Carbohydrates: Classification by Chemistry and Physiology. Food Chemistry, 57, 9-14. https://doi.org/10.1016/0308-8146(96)00055-6

[2] Holler, F.J., Skoog, D.A. and Crouch, S.R. (2009) Princípios de Análise instrumental. 6a edição.

[3] Saliba, E.O.S. and Oliveira, M.C. (2009) Evaluation of Starch Concentration in Root of Cassava Genotypes through Enzymatic Techniques, Fourier Transform Infrared 
Spectroscopy (FTIR) and Private Analysis by Laser Diffraction (Partica). 46th Annual Meeting of the Brazilian Society of Animal Science, Maringá, 14-17 July 2009, 4.

[4] Rostagno, H.S. (2005) Tabelas brasileiras para aves e suínos. Composição de alimentos e exigências nutricionais. Universidade Federal de Viçosa, Viçosa.

[5] Saliba, E.O.S., Rodriguez, N.M., Pilo-Veloso, D., et al. (2003) Estudo comparativo da coleta total com a lignina purificada como indicador de digestibilidade para ovinos em experimento com feno de Tifton 85. In: Reunião anual da sociedade brasileira de zootecnia, 40, 2003, Santa Maria. Anais... Santa Maria: Sociedade Brasileira de Zootecnia, 2003. (CD-ROM).

[6] Edin, H. (1918) Orienterandeforsok over anvanbarhetenavenpa "ledkroppsprincipen" grundad metod at best ammaen foder blandings smal barhed. Medd. Centralanst. Foersoeksvaes. Jordbruksomraadet, 165, 28. (In Swedish)

[7] Jagger, S., WisemanI, J., Cole, D.J.A., et al. (1992) Evaluation of Inert Markers for the Detection of Ileal and Faecal Apparent Digestible Values in the Pig. British Journal Nutrition, 68, 729-739. https://doi.org/10.1079/BJN19920129

[8] Cunniff, P. (1995) Official Methods of Analysis of AOAC International. 16th Edition, AOAC International, Arlington.

[9] Association of the Official Analytical Chemists (AOAC) (1995) Official and Tentative Methods of Analysis. 16th Edition, Arlington, 2000 p.

[10] Silva, D.J. (1981) Análise de alimentos: Métodos químicos e biológicos. Universidade Federal de Viçosa, Viçosa.

[11] Ufv/Saeg (2000) Sistema de análise estatísticas e genéticas. Versão 9.0., Viçosa.

Submit or recommend next manuscript to SCIRP and we will provide best service for you:

Accepting pre-submission inquiries through Email, Facebook, LinkedIn, Twitter, etc. A wide selection of journals (inclusive of 9 subjects, more than 200 journals)

Providing 24-hour high-quality service

User-friendly online submission system

Fair and swift peer-review system

Efficient typesetting and proofreading procedure

Display of the result of downloads and visits, as well as the number of cited articles

Maximum dissemination of your research work

Submit your manuscript at: http://papersubmission.scirp.org/

Or contact ajac@scirp.org 